\title{
Investigating Competition in Iran's Electricity Industry
}

\author{
Amir Bagheri ${ }^{1}$ \\ Hamid Nazeman ${ }^{2}$
}

a.bagheri@imps.ac.ir

\begin{abstract}
The transition from a structurally old-fashion and vertically integrated electric power industry to a new one in which production, distribution, and retail sale of electricity are treated separately, is usually accompanied by establishing an electricity market both at wholesale and retail sale levels. In pursuance of the success story in re-structuring the electric power industry worldwide, Iran also launched the electric power market in 1383 (AD 2004). One of the concerns of regulators in the electricity sector in every country is the extent and degree of competitiveness in the electric power market that safeguards the interest of electricity users. The present paper aims to evaluate the performance of the wholesale market for electricity within the framework of profit maximization modeling for power generating industries concerning deviation from perfect market conditions. The findings of this paper indicate that on average, power market performance in Iran deviates by 18 percent from the result expected in a competitive market.
\end{abstract}

Keywords: Re-structuring of Electric Power Industry, Marginal Cost of Power Generating Industry, Generalized Method of Moments (GMM), Competition Criterion, Lerner Index.

JEL Classification: D41, D42, L94.

1. Ph.D. in Economics. Allameh Tabataba'i University, Tehran, Iran (Corresponding Author).

2. Ph.D. in Economics, Université Libre de Bruxelles. 


\section{بررسى رقابت در صنعت برق ايران}

a.bagheri@imps.ac.ir

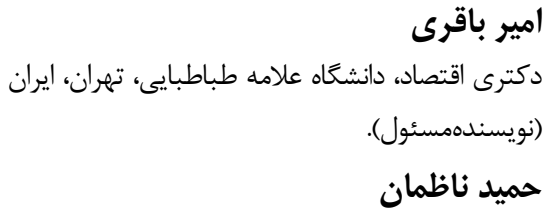

دكترى اقتصاد، دانشعاه آزاد بروكسل.

קُكيده: گذر از ساختار سنتى يكيارجه عمودى صنعت برق به ساختار جديد آن با

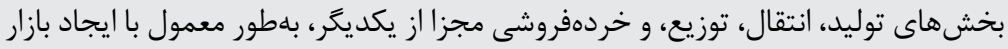

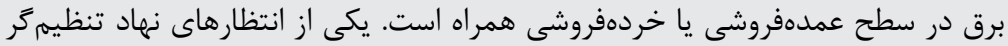
بخش برق از بازارهاى برق فعال در هر كشورى، از جمله ايران، ميزان رقابتى بودن نتايج اين بازارها در جهت حفظ منافع مصرفكنندكان است. يزوهش حاضر در جار تروب

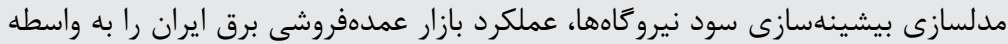

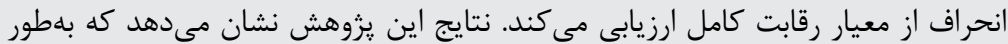

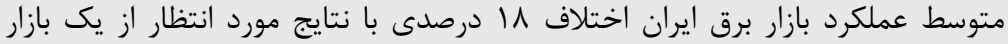
رقابتى دارد.

كليدوازهها: تجديد ساختار صنعت برق، هزينه نهايى، گشتاورهاى تعميميافته، معيار رقابتى، شاخص لرنر. طبقهبندى D41, D42, L94 :JEL. 


\section{مقدمه}

بر اساس آموزههاى اقتصادى در تعادل بازار رقابت كامل، مازاد رفاه توليدكننده و مصرفكننده

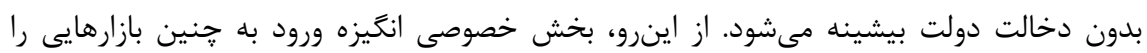

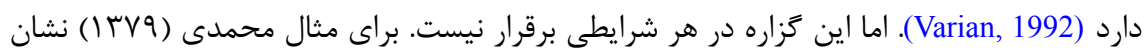
مىدهد، در شرايطى مانند ساختار سنتى صنعت برق، كه در آن انحصار طبيعى در سه بخش توليد،

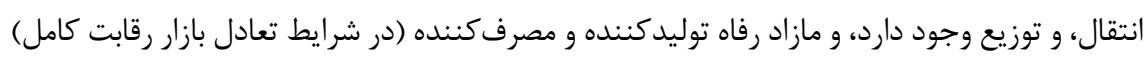
بيشينه نمىشود و بخش خصوصى انگيزه ورود به جنين بازارهايى را ندارد، دخالت دولت توجيه يذير

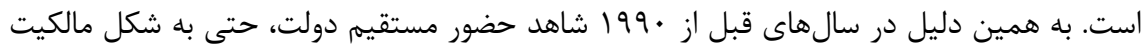

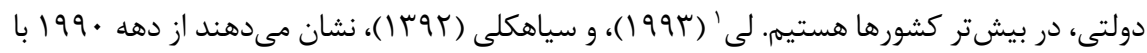
ييشرفت فناورى و حذف انحصار طبيعى ناشى از وجود صرفههاى ناشى از مقياس، دست كم در بخش بئش توليد برق، انخيزه ورود بخش خصوصى به بخش توليد برق تقويت مىشود و شاهد تغيير نكرش به به

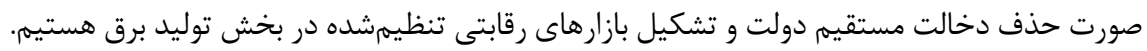

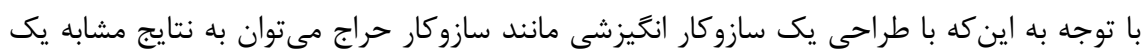

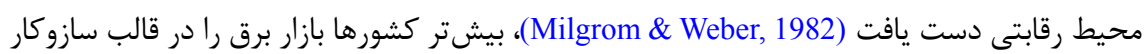

بازار عمدهروشى برق ايران به دنبال تجربه موفق برخى كشورها در زمينه بازار برق و به اميد

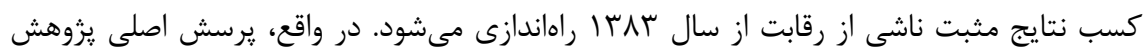

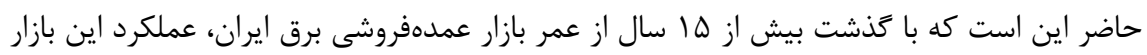

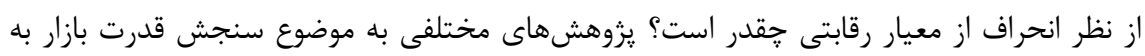

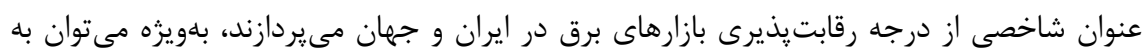

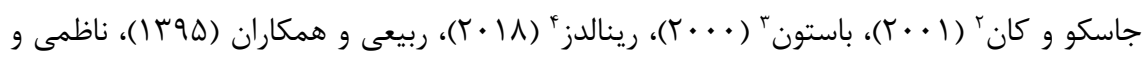

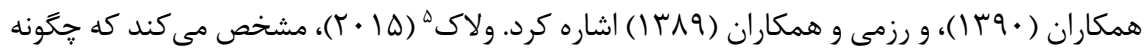
جهار عرضهكننده بزرى در بازار عمدهفرشى برق نيوزلند، قدرت بازار يكجانبه اعمال مى كنند.

1. Lai

2. Joskow \& Kahn

3. Batstone

4. Reynolds

5. Wolak 


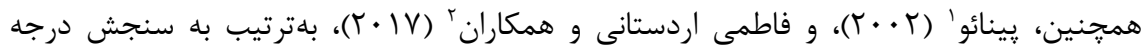

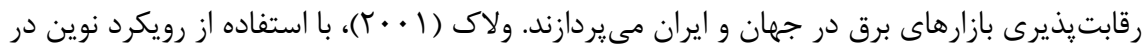

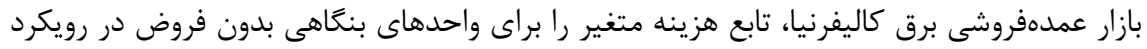

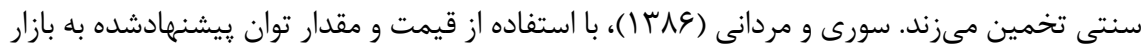

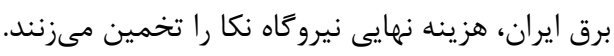

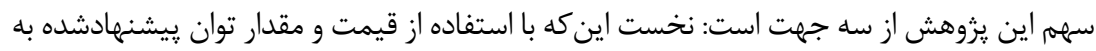

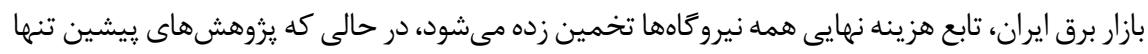

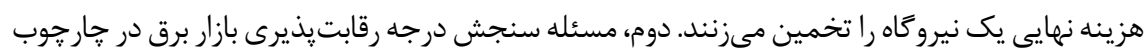

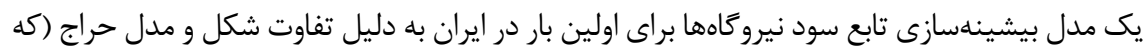

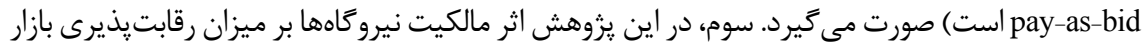

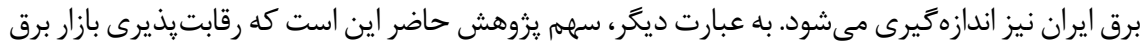

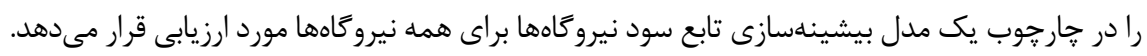

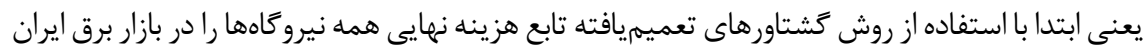

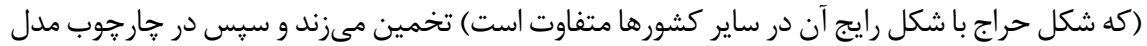

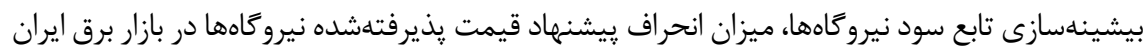

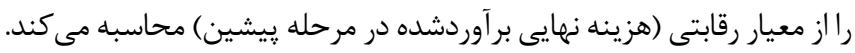

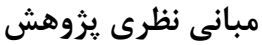

در حال حاضر، اعتقاد بر اين است كه بخش توليد برق داراى شرايط رقابت است و تشكيل بازار رقابتى در اين بخش مىتواند آثار مثبت اقتصادى به همراه داشته باشد (Joskow \& Kahn, 2001).

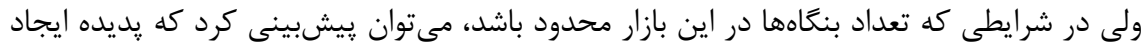

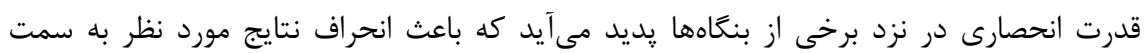

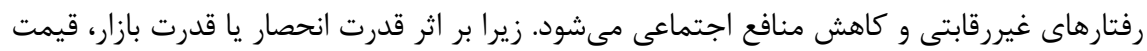

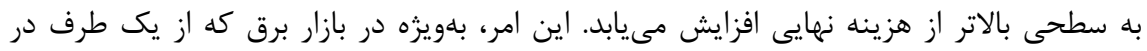

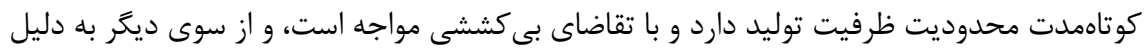


غيراقتصادى بودن ذخيره توليد، نيازمند برابرى لحظهاى بين توليد و تقاضاست، بسيار محتمل است.

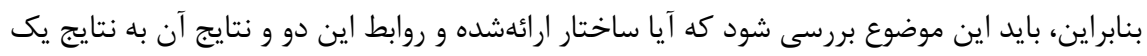

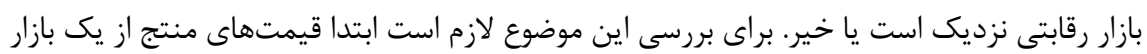

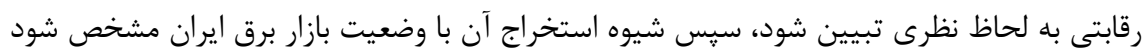

$$
\text { و شاخصها و آزمونهاى لازم براى انجام ارزيابىها تبيين كرددد. }
$$

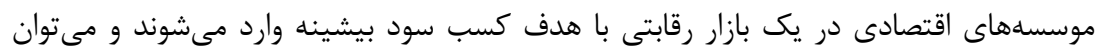

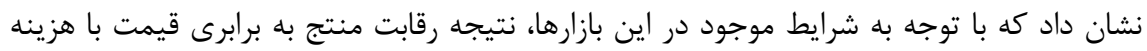

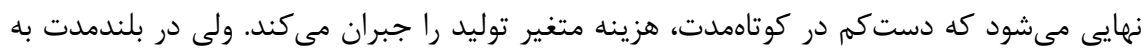

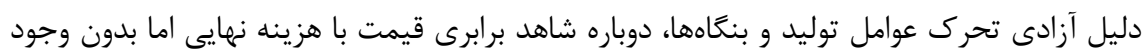

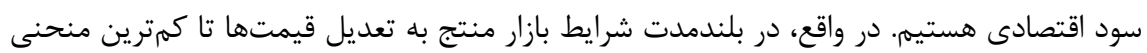

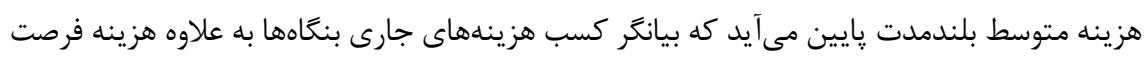

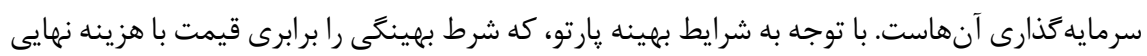

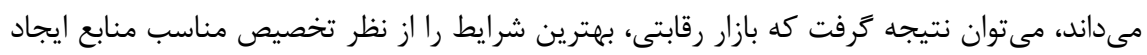

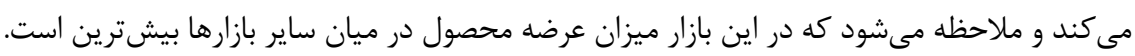

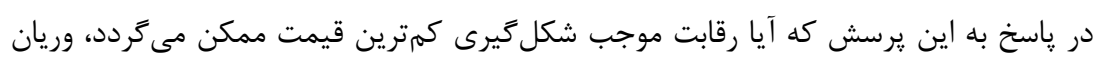

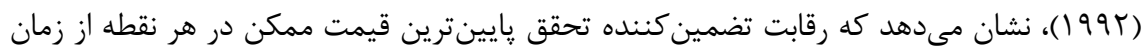

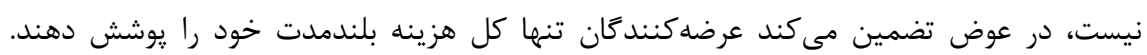

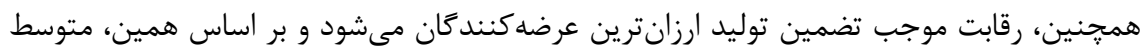

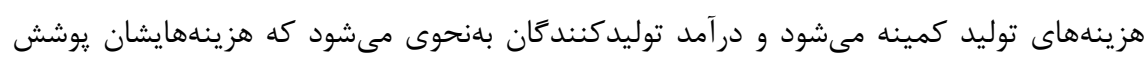

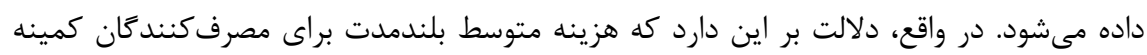

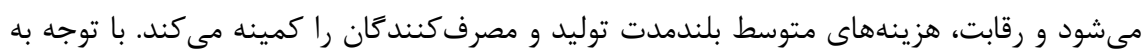

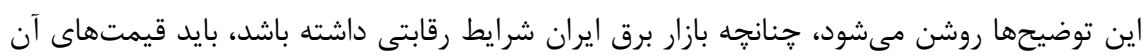

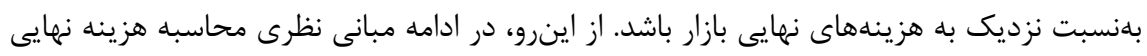

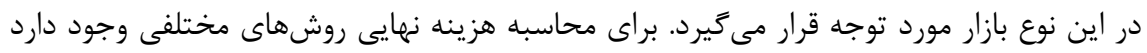

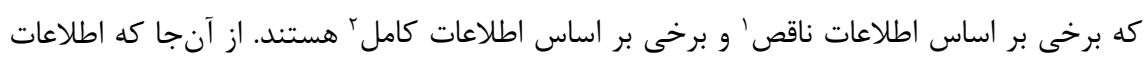

1. Imperfect Information

2. Perfect 
مربوط به هزينه بنكاههاى توليد برق منتشر نمىشود و كاه مشاهده مى كردد كه مالكان اين بنكاهها

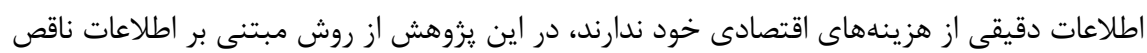
براى استخراج هزينه نهايى بنگًاههاى توليد برق استفاده مىشود.

\section{تابع هزينه نهايى در حالت اطلاعات ناقص و بازار برق با حراج قيمت يكسان}

بلهور معمول، در بازارهاى برق اطلاعات مربوط به هزينه توليد در نيرو ماهها در اختيار

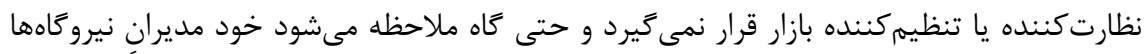

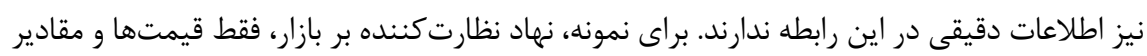

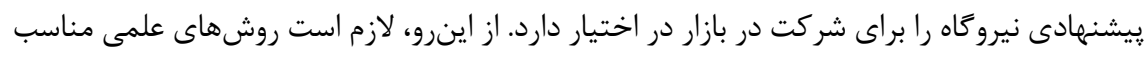

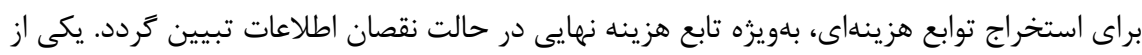

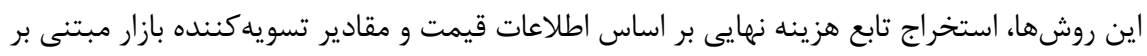
رفتار بيشينهسازى سود توسط بنغاه است.

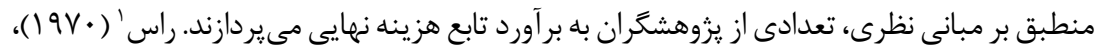

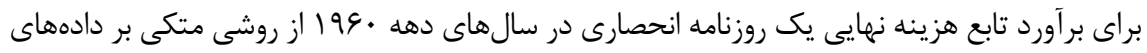

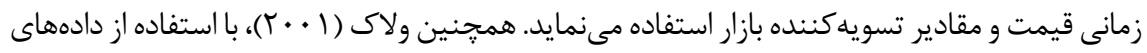

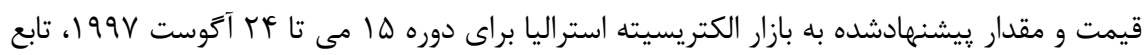

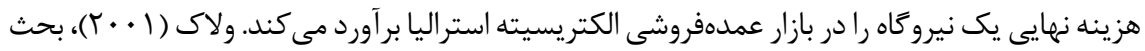

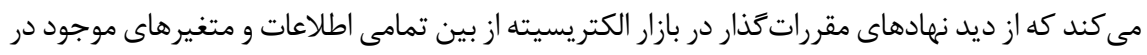

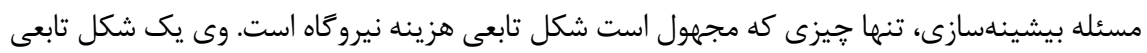

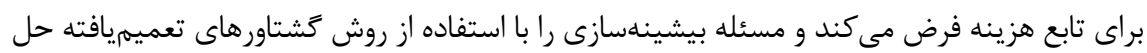

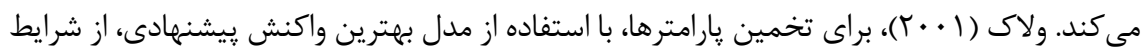

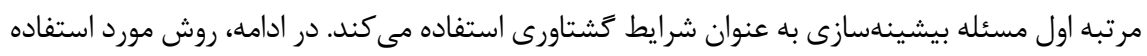

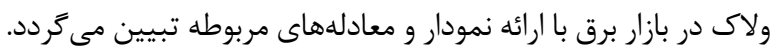

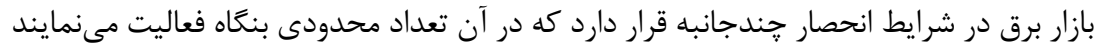

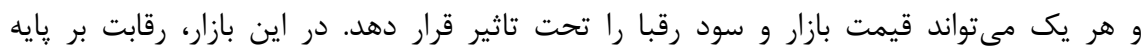

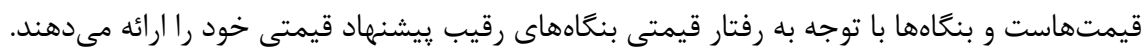


شكل (1)، تابع تقاضاى بازار را در شرايط انحصار קندجانبه نشان مىدهد. جنانجه تقاضاى كل بازار

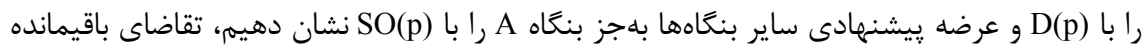

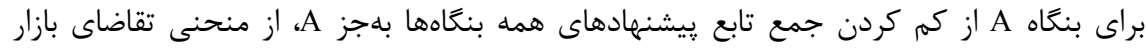

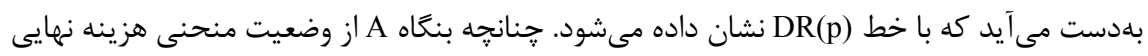

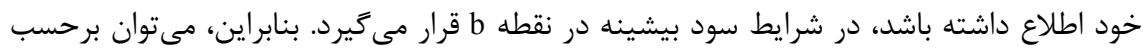

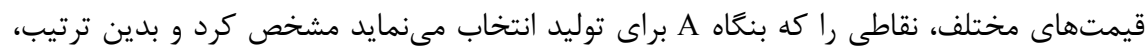

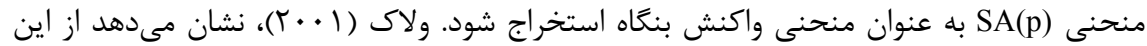

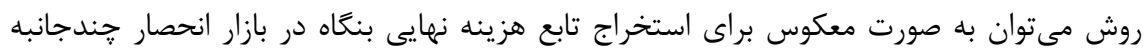

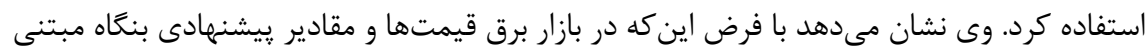

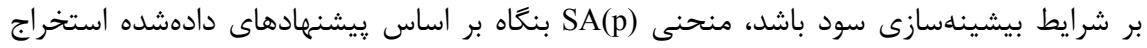

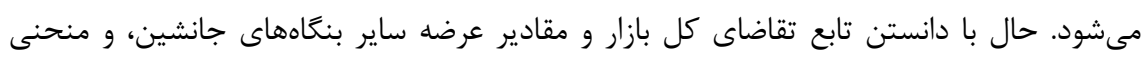
مى SA(p)

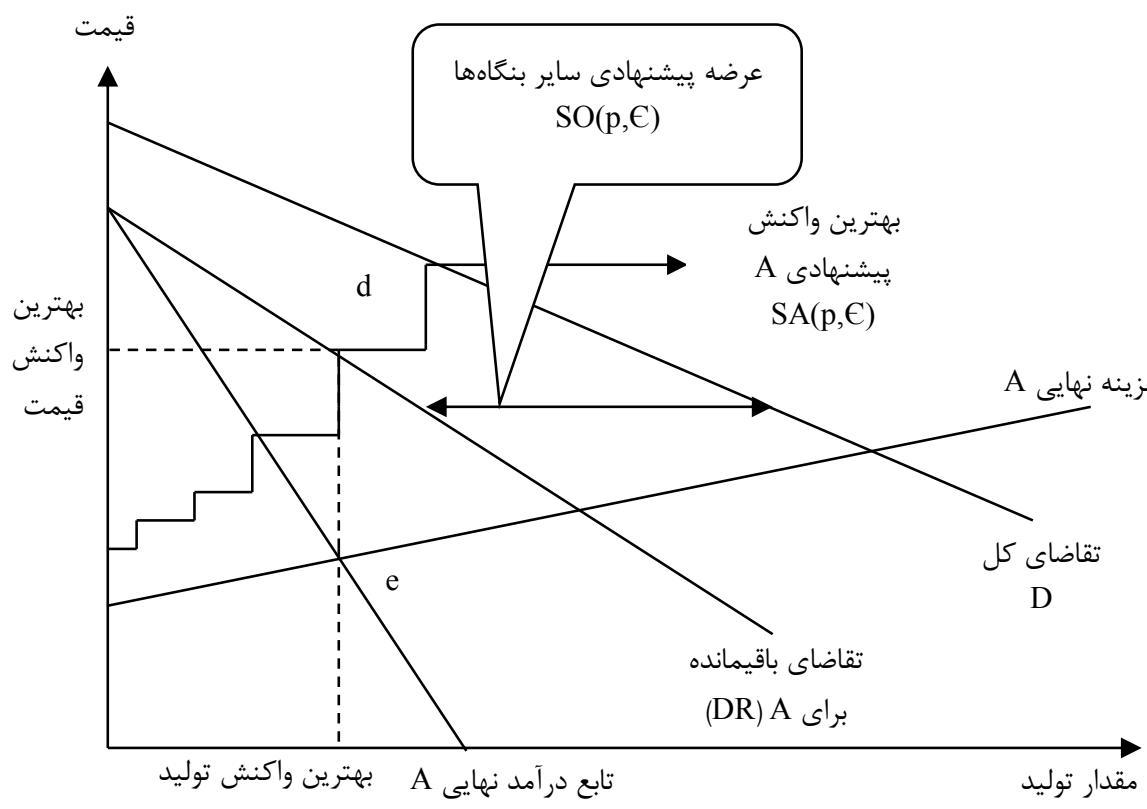

شكل ا: نحوه تصميمكيرى يك بنكاه در شرايط انحصار حندجانبه فروش نائ 
توليدكنندكان در بيشتر بازارهاى برق دنيا، مقادير توليدشان را در هر دوره يكساعته يا

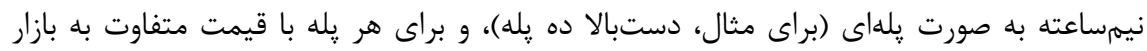
ييشنهاد مى دهند. ايده اساسى اين است كه توليدكنندكان موجود در بازار برق، با فرض عقلايى بودن توليدكنند

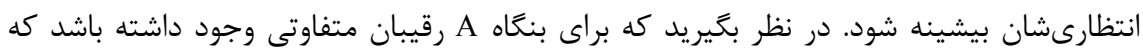

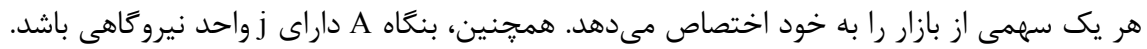

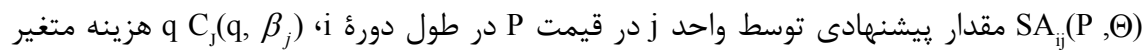

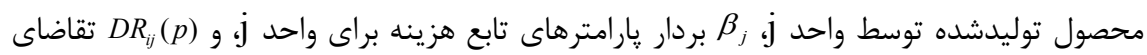

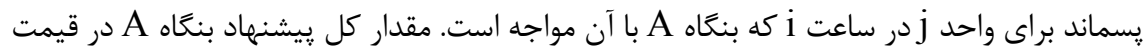
$S A_{i}(P, \Theta)=\sum_{j=1}^{J} S A_{i j}(P, \Theta)$

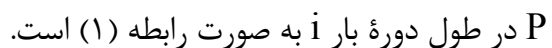
با توجه به علايم بالا، سود متغير محققشده بنگاه A در طول روز d به صورت رابطه (r) درمىآيد. $\Pi_{d}(\Theta, \varepsilon)=\sum_{i=1}^{24}\left[D R_{i}\left(P_{i}\left(\varepsilon_{i}, \Theta\right), \varepsilon i\right) P_{i}\left(\varepsilon_{i}, \Theta\right)-\sum_{j=1}^{J} C_{j}\left(S A_{i j}\left(P_{i}\left(\varepsilon_{i}, \Theta\right), \Theta\right), \beta_{j}\right)\right]$

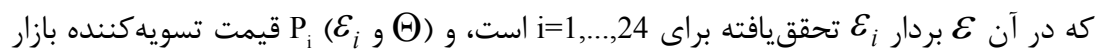

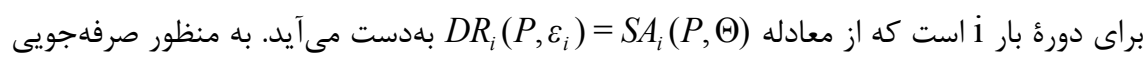

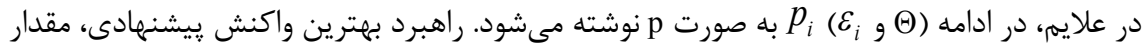
انتظارى (ع) سود انتظارى روزانه و براى استخراج يارامترهاى تابع هزينه سطوح واحد نيروگاهى، از روش تخمين گشتاورهاى تعميميافته (GMM)' براى همه روزها (d) استفاده مىشود. بنابراين، از شرط مرتبه

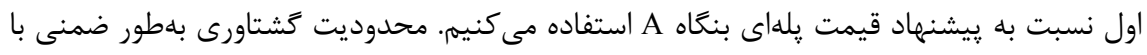
$E_{\varepsilon}\left(\frac{\partial \Pi_{d}\left(\Theta_{d}, \varepsilon\right.}{\partial P_{k m}}\right)=0$ استفاده از شرايط مرتبه اول جنين است: معادله (זّ)، تعداد J×K را تا محدوديت گشتاورى تعريف مى كند كه براى تخمين پارامترها توابع هزينه نهايى مورد استفاده قرار مى گيرد. نمونه همسان اين محدوديت گشتاورى مانند رابطه (أ) است: 
$\frac{\partial \Pi_{d}\left(\Theta_{d}, \varepsilon\right)}{\partial P_{k m}}=\sum_{i=1}^{24}\left[\left(D R_{I}^{\prime}\left(p_{I}\left(\varepsilon_{i}, \Theta\right), \varepsilon_{i}\right) P_{i}\left(\varepsilon_{i}, \Theta\right)+\left(D R_{i}\left(P_{i}\left(\varepsilon_{i}, \Theta\right), \varepsilon_{i}\right)\right)\right.\right.$

$\left.-\sum_{j=1}^{J} C^{\prime} j\left(S A_{i j}\left(P_{i}\left(\varepsilon_{i}, \Theta\right)\right), \beta_{j}\right)\left(\frac{\partial S A_{i j}}{\partial P_{i}}\right)\right) \frac{\partial P_{i}}{\partial P_{k m}}$

$\left.-\sum_{j=1}^{J} C^{\prime}\left(S A_{i j}\left(P_{i}\left(\varepsilon_{i}, \Theta\right)\right), \beta_{j}\right) \frac{\partial S A_{i j}}{\partial P_{k m}}\right]$

كه Pi نشاندهنده قيمت تسويه كننده بازار در دورة بار i است. فرض كنيد كه (م) نشاندهنده

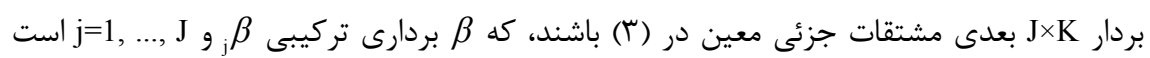

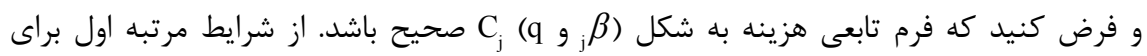

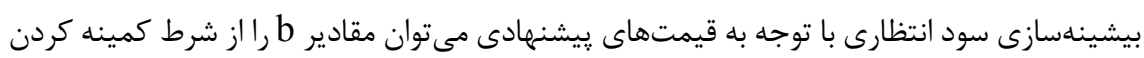
رابطه (ه) بلهدست آورد كه تخمين سازكًارى از $\beta$ است.

$\left[\frac{1}{D} \sum_{d=1}^{D} J_{d}(b)\right],\left[\frac{1}{D} \sum_{d=1}^{D} l_{d}(b)\right]$

فرض كنيد b(I) نشاندهنده اين تخمين سازگار $\beta$ باشد، و I نشاندهنده ماتريس واحد مورد

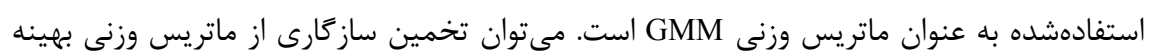
$V_{D}(b(I))=\frac{1}{D} \sum_{d=1}^{D} l_{d}(b(I)) l_{d}(b(I))^{\prime}$ ا به صورت رابطه (ع) GMM و تخمينزننده GMM مقدار b را بdدست مى bهد كه عبارت (V) را كمينه مى كند:

$\left[\frac{1}{D} \sum l_{d}(b)\right]^{\prime} V_{D}\left(b(I){ }^{1}\left[\frac{1}{D} \sum_{d=1}^{D} l_{d}(b)\right]\right.$

آخرين مرحله ضرورى براى اجراى اين تكنيك، انتخاب فرم تابعى براى تابع هزينه نهايى هر واحد است. فرض كنيد مالك بنحاه A دو نيروگاه برق دارد. نيرو

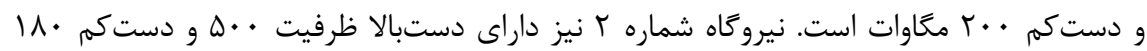

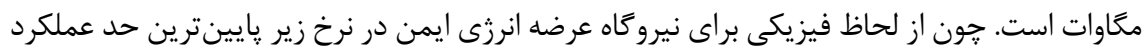

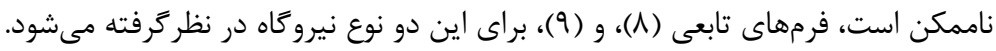

$C_{1}^{\prime}\left(q, \beta_{1}\right)=\beta_{10}+\beta_{11}(q-200)+\beta_{12}(q-200)^{2}$

$C_{2}^{\prime}\left(q, \beta_{2}\right)=\beta_{20}+\beta_{21}(q-180)+\beta_{22}(q-180)^{2}$ 
اين فرمهاى تابعى در رابطه (ه)، براى تشكيل محدوديتهاى گشتاورى نمونه جايخذارى مىشود

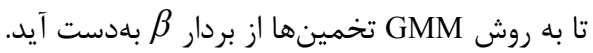
$\beta=\left(\beta_{10}, \beta_{11} \cdot \beta_{12}, \beta_{20}, \beta_{21}, \beta_{22}\right)^{\prime}$ نياز به اشاره است در روش كشتاورهاى تعميميافته، پارامترها بر اساس كمينه كردن تابع هدف

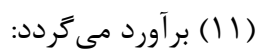

$K=S(B)^{\prime} V S(B)$

كه در آن B بردار بارامترها با ابعاد S(B) بردار محدموديت Fثتاورى با ابعاد (m×1) است.

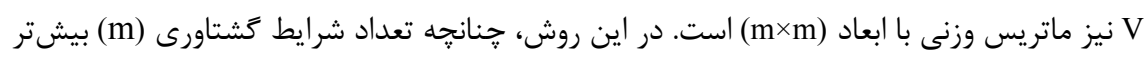

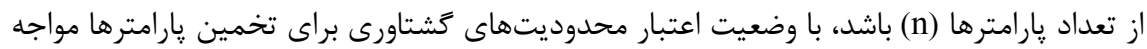
$H_{0}: m>n$

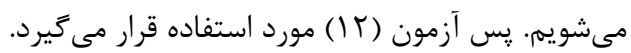
$H_{1}: m \leq n$ همجنين، مقدار بهينه تابع هدف (K)، بلهطور مجانبى به صورت متغير تصادفى كاى ـ دو با درجه

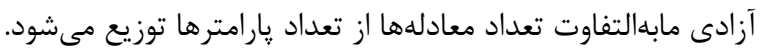

تاكنون شرايط مرتبه اول بيشينهسازى سود يك بنكاه در بازار برق با مدل حراج قيمت يكسان

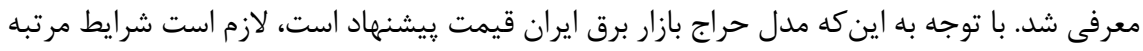

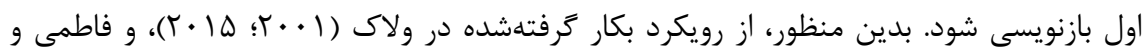

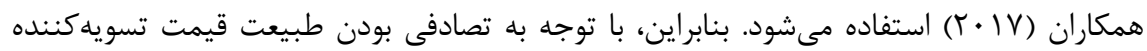

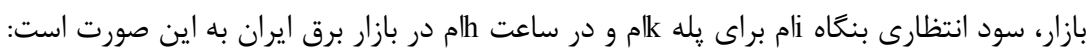
$\pi_{i h}^{k}=\left[S_{i h}^{k}\left(P_{i h}^{k}\right) P_{i h}^{k}-C_{i h}^{k}\right] I_{i h}^{k}$

$I_{\text {ih }}^{k}=\left\{\begin{array}{l}1 \text { if } P_{i h}^{k} \leq M C P_{h} \\ 0 \text { if } P_{i h}^{k} \geq M C P_{h}\end{array}\right.$

$C_{i h}^{k}=\left[C_{i h}\left(\sum_{l=1}^{K} S_{i h}^{l}\left(P_{i h}^{l}\right)\right)-C_{i h}\left(\sum_{l=1}^{K-1} S_{i h}^{l}\left(P_{i h}^{l}\right)\right)\right]$

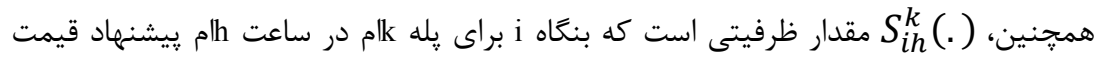

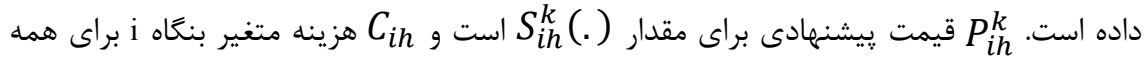




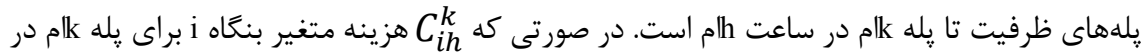

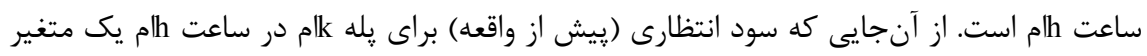

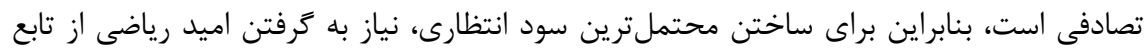
سود يس از واقعه است، يعنى:

$E\left(\pi_{i h}^{k}\right)=\int_{-\infty}^{+\infty}\left[\left(S_{i h}^{k}\left(P_{i h}^{k}\right) P_{i h}^{k}-C^{k}\right) I_{i h}^{k}\right] f_{M C P_{h}}\left(M C P_{h}\right) d\left(M C P_{h}\right)=\left[S_{i h}^{k}\left(P_{i h}^{k}\right) P_{i h}^{k}-\right.$ $\left.C^{k}\right] \int_{P_{i h}^{k}}^{+\infty} f_{M C P_{h}}\left(M C P_{h}\right) d\left(M C P_{h}\right)=\left[S_{i h}^{k}\left(P_{i h}^{k}\right) P_{i h}^{k}-C^{k}\right]\left[1-F_{M C P_{h}}\left(P_{i h}^{k}\right)\right]$ بنابراين، كل سود قبل از واقعه بنكاه i در ساعت h به صورت رابطه (V) است:

$E\left(\pi_{i h}^{k}\right)=\sum_{k=1}^{K}\left[S_{i h}^{k} P_{i h}^{k}-C^{k}\right]\left[1-F_{M C P_{h}}\left(P_{i h}^{k}\right)\right]$

بنابراين، مشابه اثبات انجامشده در شرايط مرتبه اول براى يله klم واحد iام در ساعت h به صورت

$\frac{P_{i h}^{k}-C_{i h}^{\prime}\left(S_{i h}^{k}\left(P_{i h}^{k}\right)\right)}{P_{i h}^{k}}=-\frac{1}{e_{R D, P_{i h}^{k}}^{k}}$

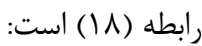

كه

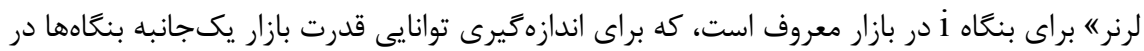

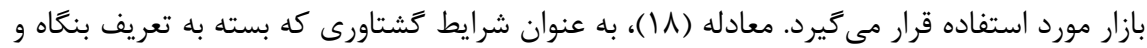

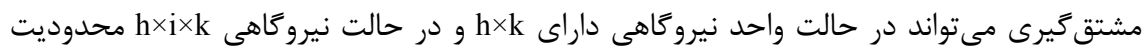

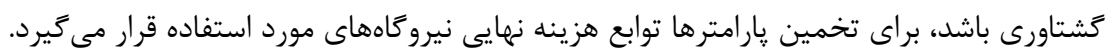

بر آورد تابع هزينه نهايى واحدهاى نيروگَاهى با استفاده از روش كَتاور تعميهيافته تكرارى با توجه به اين كه رابطه (1) به عنوان شرايط گشتاورى معرفى مىشود: $E\left[\frac{P_{i h}^{k}-C_{i h}^{\prime}\left(s_{i h}^{k}\left(P_{i h}^{k}\right)\right)}{P_{i h}^{k}}-\frac{1}{e_{R D, P_{i h}^{k}}^{k}}\right]=E[m(\theta)]=0$

كه در آن براى هر واحد نيروگاهى i به تعداد h×k شرط گشتاورى وجود دارد. با توجه به اين كه

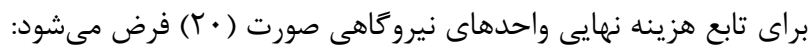


$M C=\alpha+\beta_{1}\left(q-q_{\min }\right)+\beta_{2}\left(q-q_{\min }\right)^{2}$

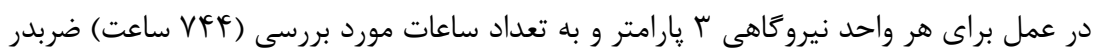

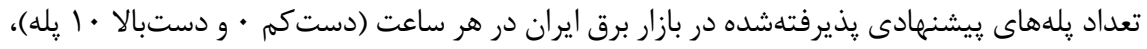

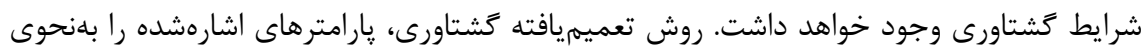
انتخاب مى كند كه عبارت (Iآ) كمينه شود:

$J_{T}=m(\theta)^{\prime} W m(\theta)$

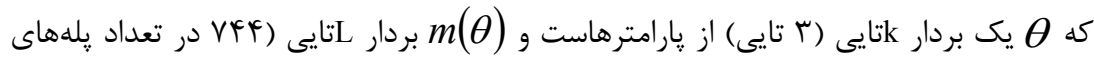

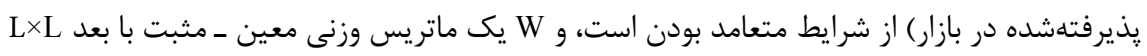

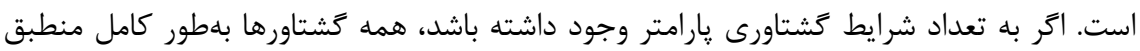

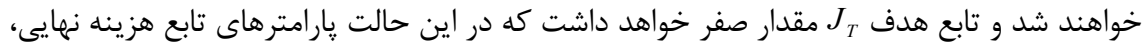

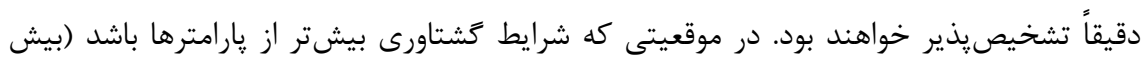

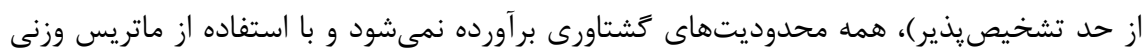

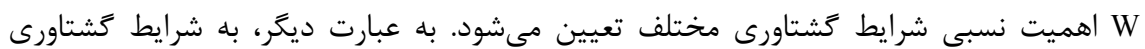
با ناطمينانى كمتر وزن بيشترى داده مىشود. روشهاى مختلفى براى تخمين ماتريس S وجودي

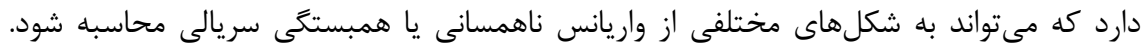

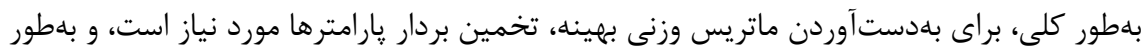

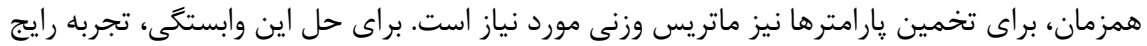

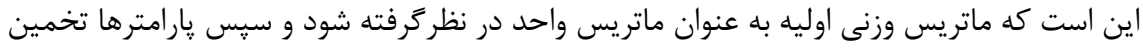

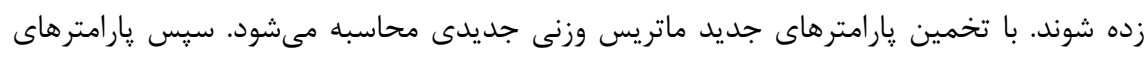

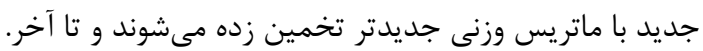

$W_{0}=I$

$\hat{\theta}_{1}=\operatorname{argmin} \quad m(\theta)^{\prime} W_{0} m(\theta)$

$W_{1}=f\left(\hat{\theta}_{1}\right)$

$\hat{\theta}_{2}=\operatorname{argmin} \quad m(\theta)^{\prime} W_{1} m(\theta)$

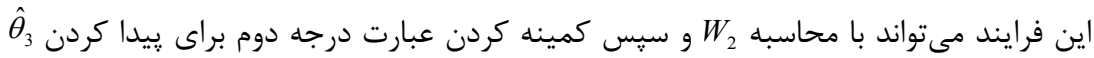

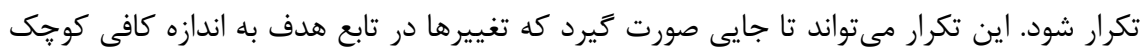
باشد (قضيه كوشى). بلهور كلى، تكرار تا مرحله برآورد 
مرحلهاى معروف است و اغلب روش تعميميافته كشتاورهاى تكرارشونده ناميده مىشود. برنامه اين بخش با استفاده از نرمافزار متلب' نوشته مىشود. تكنيك تعميميافته گشتاورها براى كمينهسازى

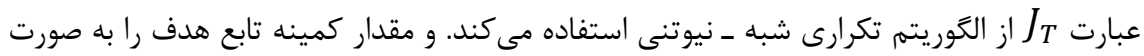
موضعى يِيدا مى كند. به اين صورت كه ابتدا با يك نقطه اوليه براى بردار پارامترها و ماتريس وزنى كه

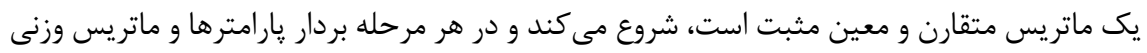

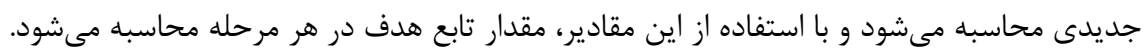

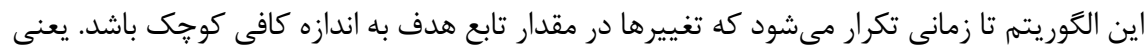

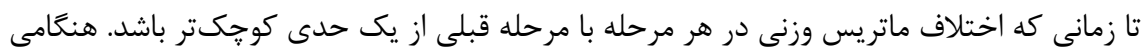

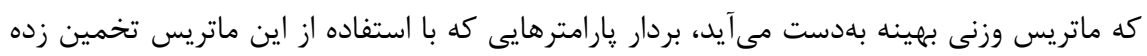

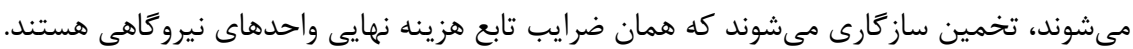

\section{برازش مدل}

اگر مدل بلهور تشخيصيذير باشد، در آن صورت براى هر محدوديت يك پارامتر وجود دارد،

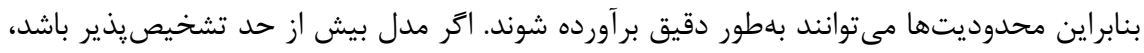

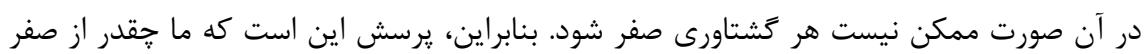

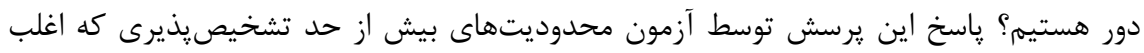

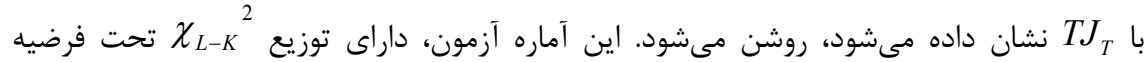

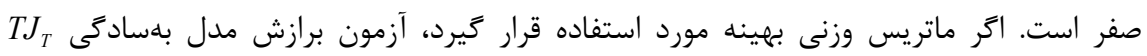

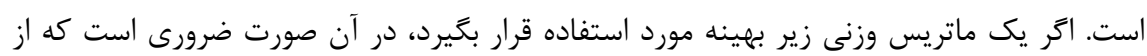

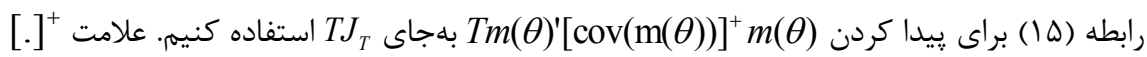
نشاندهنده شبهمعكوس است، جون ماتريس واريانس ـ كوواريانس يك ماتريس منفرد (معكوسيذير

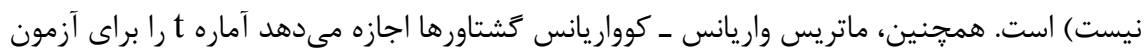
كشتاورهاى فردى محاسبه كنيم. 


\section{آزمون تشخيصيذيرى بيش از حد يارامترها'}

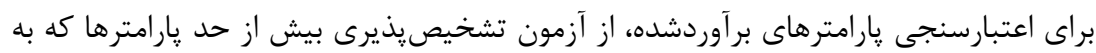

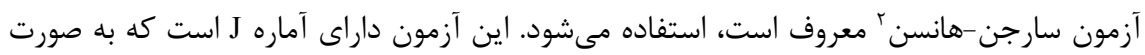

$$
J \equiv T \widehat{m}(\widehat{\theta})^{\prime} \widehat{W}^{-1} \widehat{m}(\widehat{\theta}) \stackrel{a}{\rightarrow} \chi_{L-K}^{2}
$$

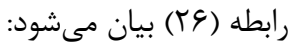

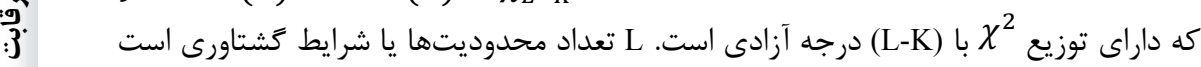

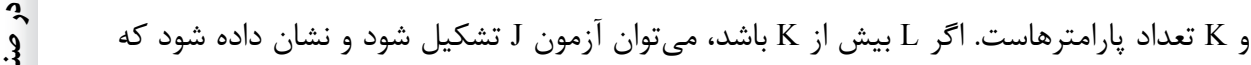

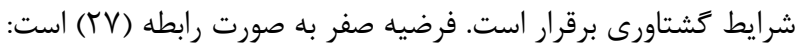

$H_{0}: E[m(\theta)]=0$ از نظر مفهومى، اين آزمون به اين معناست كه آيا

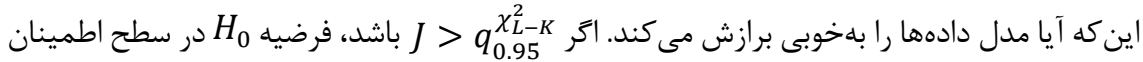
هو درصد رد مىشود و يارامترهاى برازششده اعتبار ندارند.

\section{شاخصهاى اندازمكيرى ميزان رقابتيذيرى بازار}

يكى از مهمترين اقدامهايى كه در تحليل هر بازارى توسط تحليلخران بايد انجام شود، اندازهيرى

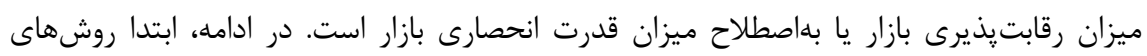
كلى اندازهيرى عامل قدرت بازار ارائه مى

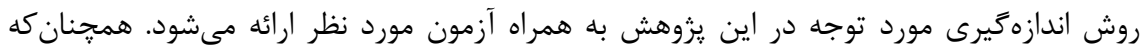

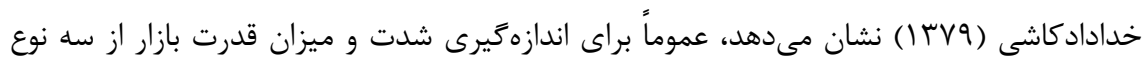

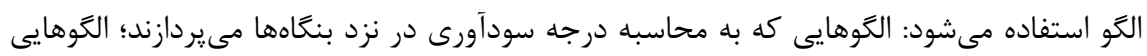
كه به محاسبه اخلال در رفاه اجتماعى و تخصيص منابع مى يردازند؛ و الكوهايى كه ميزان تمركز را برد در بازار مورد سنجش قرار مىدهند. يكى از مرسومترين روشها كه در دومين گروه قرار مى شاخص لرنر است. 


\section{شاخص لرنر'}

شاخص لرنر، ميزان فاصله از رقابت را بر اساس شكاف نسبى بين قيمت و هزينه نهايى اندازهخيرى

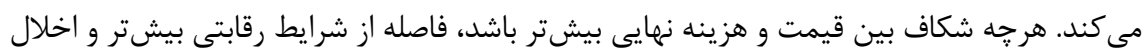
بيشترى در رفاه اجتماعى و تخصيص منابع ايجاد مىشود. از طرف ديگر، در بازار انحصارى ميزان

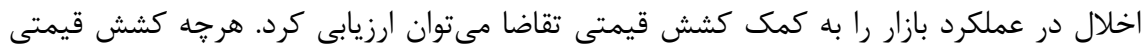

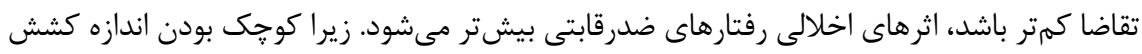

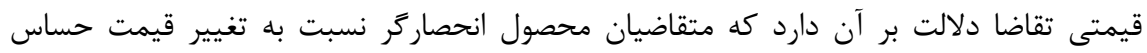

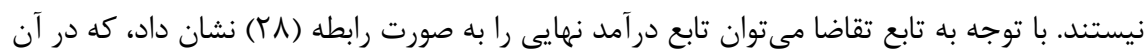

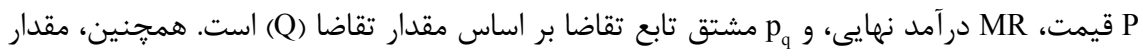

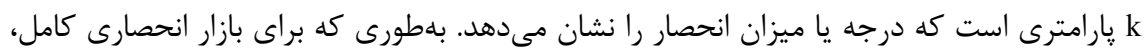

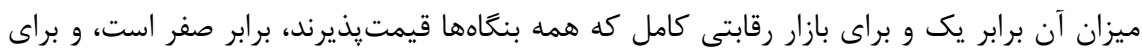

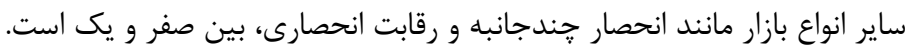

$\operatorname{MR}(k)=P+k P q \times Q$

در شرايط سود بيشينه، برابرى درآمد نهايى (MR) با هزينه نهايى (MC) برقرار است (رابطه وج).

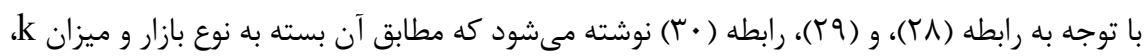
شاخص لرنر رابطه معكوس با كشش تقاضا دارد.

$M R(k)=M C$

$P+k \times P q \times Q=M C \Rightarrow P-M C=-k \times P q \times Q \Rightarrow \frac{P-M C}{P}=-\frac{k}{\epsilon}=L$

همان گونه كه اشاره شد، براى آزمون ميزان رقابتيذيرى بازار برق بايد ميزان نزديكى نسبى

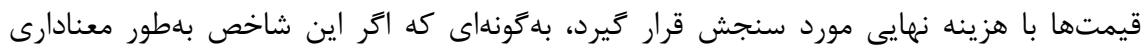

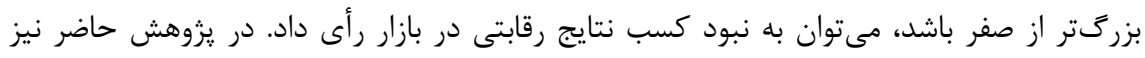

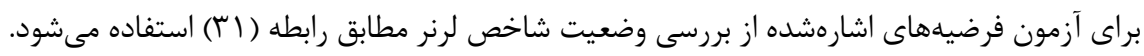
$H_{0}: \mu_{L}=0$

$H_{1}: \mu_{L} \succ 0$

1. Lerner Index 
$\mu_{L}$

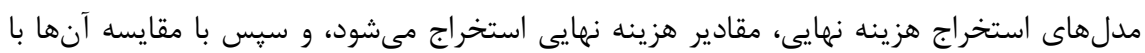
قيمتهاى عملكردى بازار، شاخص لرنر استخراج مى گردد.

\section{بر آورد يارامتر هاى تابع هزينه نهايى واحدهاى نيروگاهى}

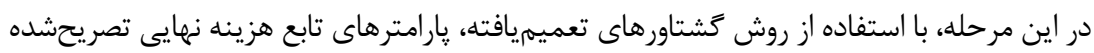

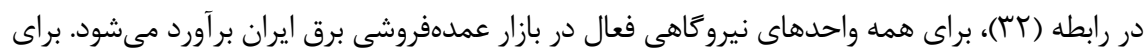

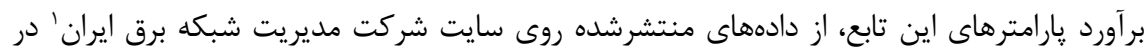

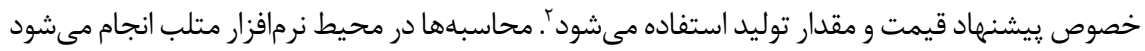
و نتايج متوسط ضرايب بر آوردشده تابع هزينه نهايى واحدهاى نيروكاهى در جدول ( ) ارائه مىشود. $M C=\alpha+\beta_{1}\left(q-q_{\text {min }}\right)+\beta_{2}\left(q-q_{\text {min }}\right)^{2}$

جدول ا: متوسط ضرايب بر آوردشده تابع هزينه نهايى واحدهاى نيروكاهى

\begin{tabular}{|c|c|c|}
\hline \multirow{2}{*}{ ن متغير } & متوسط ضرايب & انحراف معيار \\
\hline & Rials / Mwh & Rials / Mwh \\
\hline عرض از مبدا & rgf।qf & $194 \wedge 1$ \\
\hline$\left(q-q_{\text {minimum }}\right)$ & $9 / 4$ & $1 / 1$ \\
\hline$\left(q-q_{\text {minimum }}\right)^{2}$ & $r / r$ & • \\
\hline
\end{tabular}

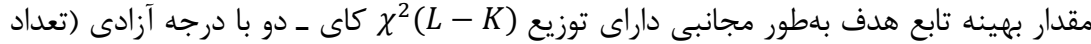

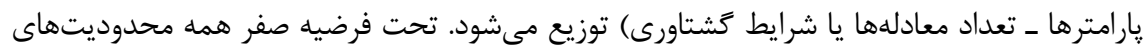
گشتاورى (به عنوان تعداد ابزارها) تحميلشده براى تخمين يارامترها معتبر هستند. مقدار بهينه تابع

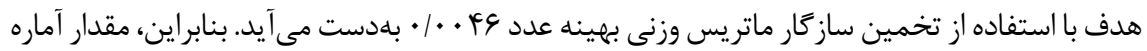

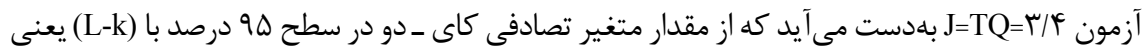
1. https://www.igmc.ir/Electronic-Services/Power-Market-Deputy/Reports ז. بر اساس سايت شركت مديريت شبكه، اطلاعات سعץ واحد نيروكاهى موجود در بازار برق ايران در شهريور

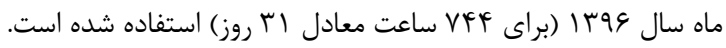




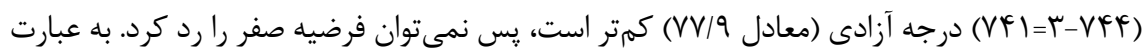

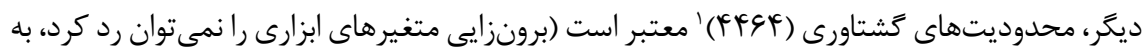
اين دليل كه مسئله بيشينهسازى سود براى واحدهاى نيرو گاهى در ساعتهاى مختلف مستقل از يكديگر هستند)، و بهطور متوسط رفتار بيشينهسازى سود واحدهاى نيروگاهى را نمىتوان رد كرد. نتايج رديف 1

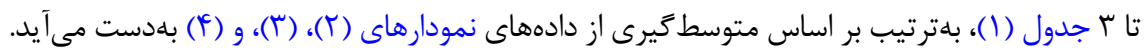

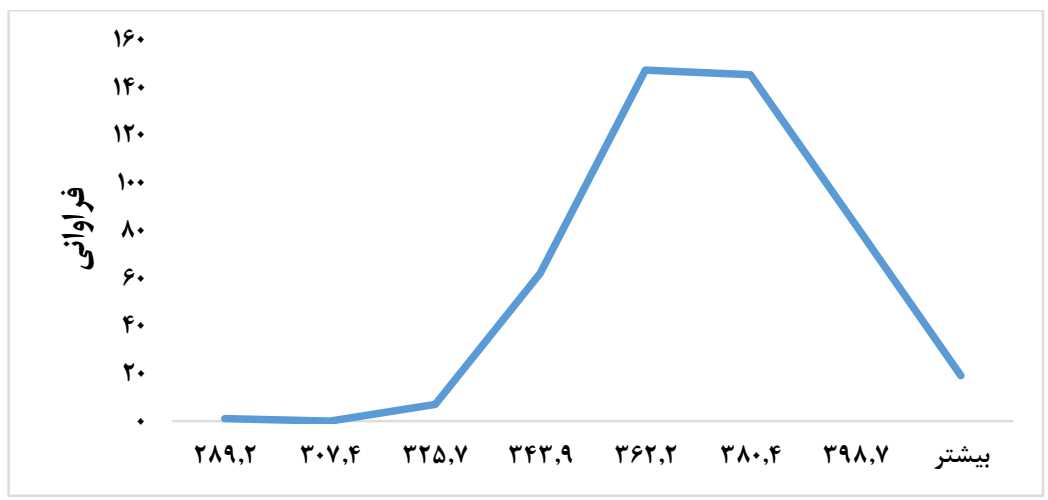

نمودار r: توزيع ضريب $\alpha$ تابع هزينه نهايى واحدهاى نيروكاهى

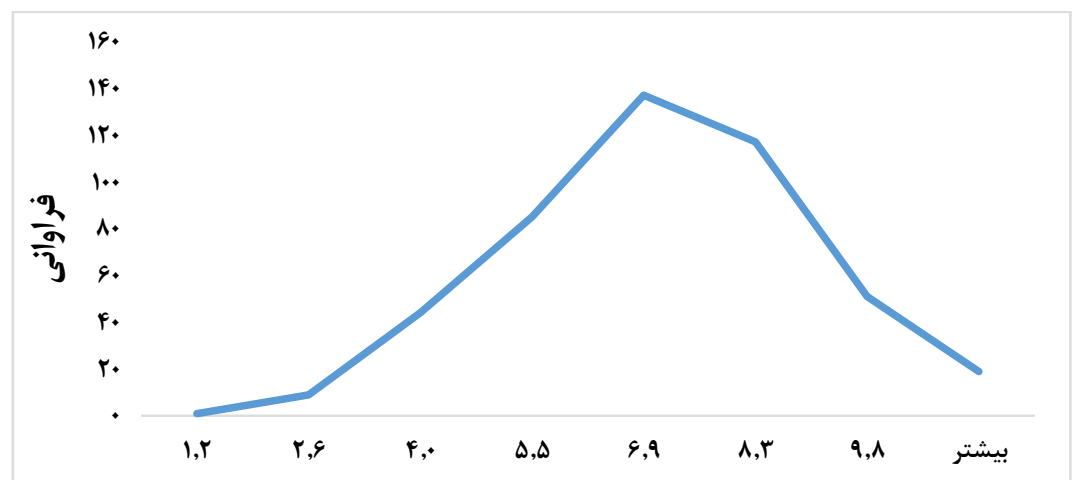

نمودار Гّ: توزيع ضريب

I. اين محدوديتها و شرايط گشتاورى از حاصل VFF VF ساعت) در تعداد يلههاى يِيشنهادى يذيرفتهشده در هر ساعت بهدست مى آيد كه بيانكر همان تعداد محدوديتها

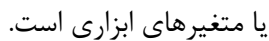




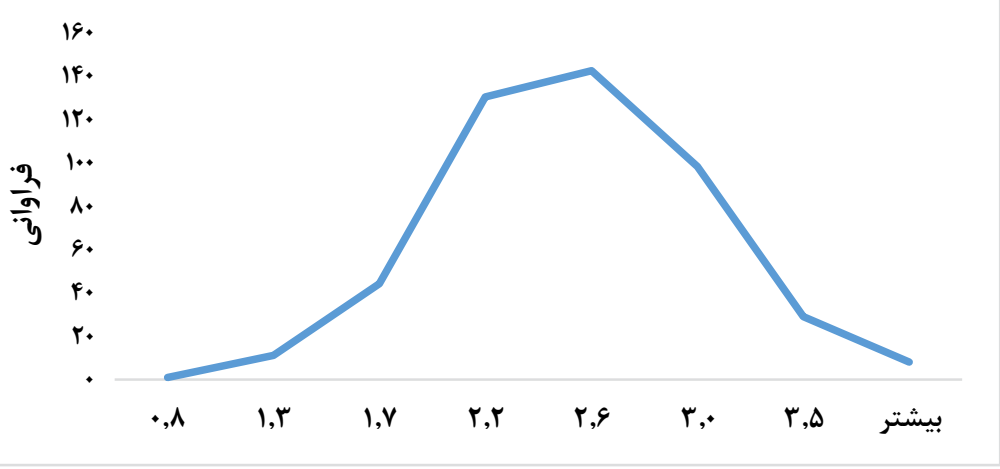

نمودار f: توزيع ضريب

بر آورد شاخص لرنر

براى قضاوت در خصوص انحراف بازار برق ايران، از معيار رقابتى سمت جٍٍ شاخص لرنر براى هر

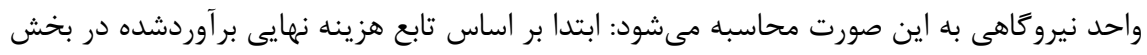

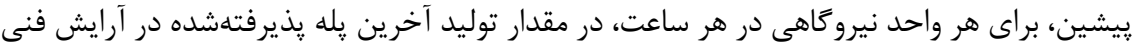

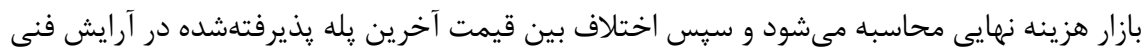

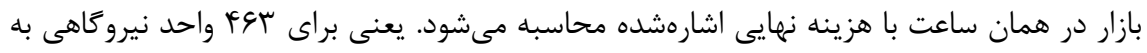

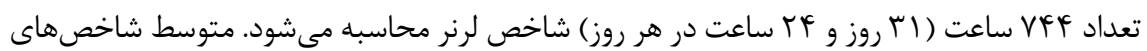

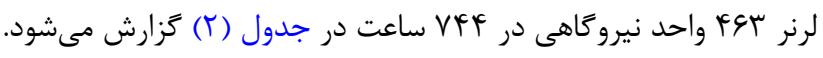

جدول r: شاخص لرنر

\begin{tabular}{|c|c|}
\hline انحراف معيار شاخص لرنر & ميانكين شاخص لرنر \\
\hline.$/ r G F$ & . /Nא \\
\hline
\end{tabular}

همانطور كه ملاحظه مى

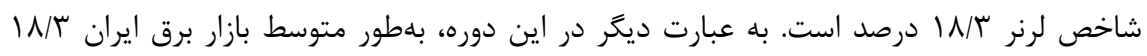

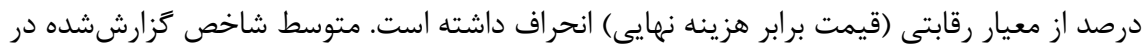


جدول (r)، بر اساس مشاهدهاى نمودار (ل) محاسبه مىشود. نمودار (ه)، توزيع تجمعى شاخص لرنر

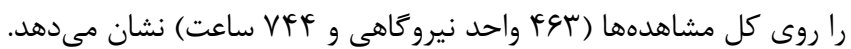

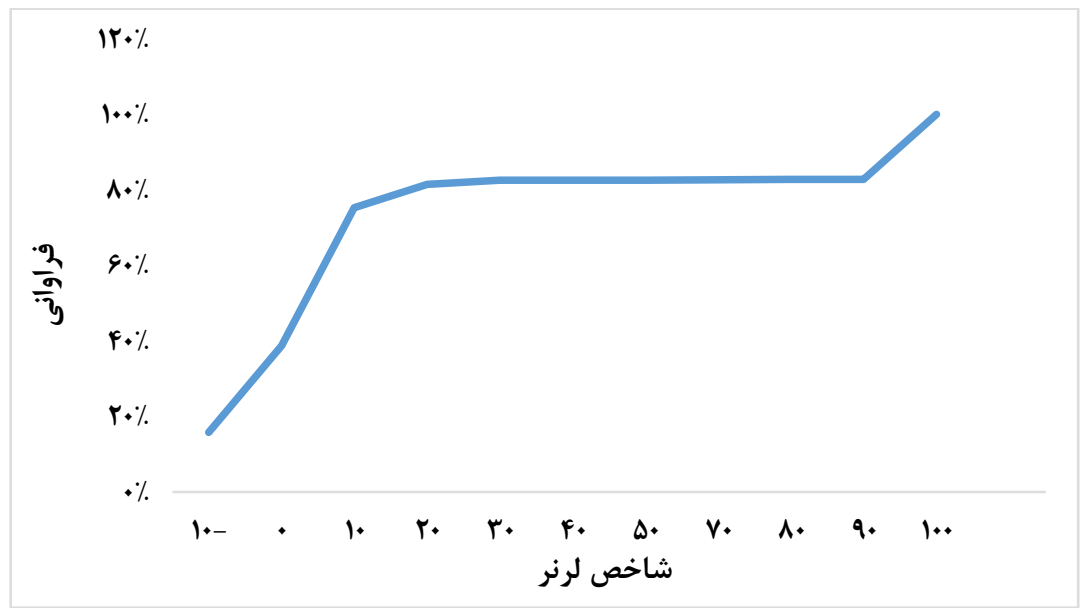

نمودار ه: توزيع تجمعى شاخص لرنر (براى همه واحدها)

همان طور كه مشاهده مى گردد، در • ^ درصد ساعات، شاخص لرنر • ا درصد و كمتر است و بازار

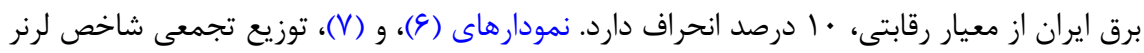

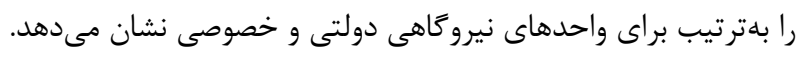

$1 T \cdot \%$

$1 \cdots \%$

$\begin{array}{ll}\frac{2}{2} & 1 . \% \\ \frac{9}{3} & 4 . \% \\ & 4 . \%\end{array}$

$f . \%$

$r \cdot \%$

$\cdot \%$

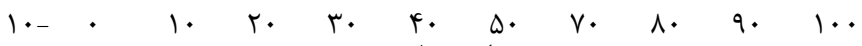
شاخص لرنر 
همانطور كه مشاهده مى درصد و كمتر است.

$1 T \cdot \%$

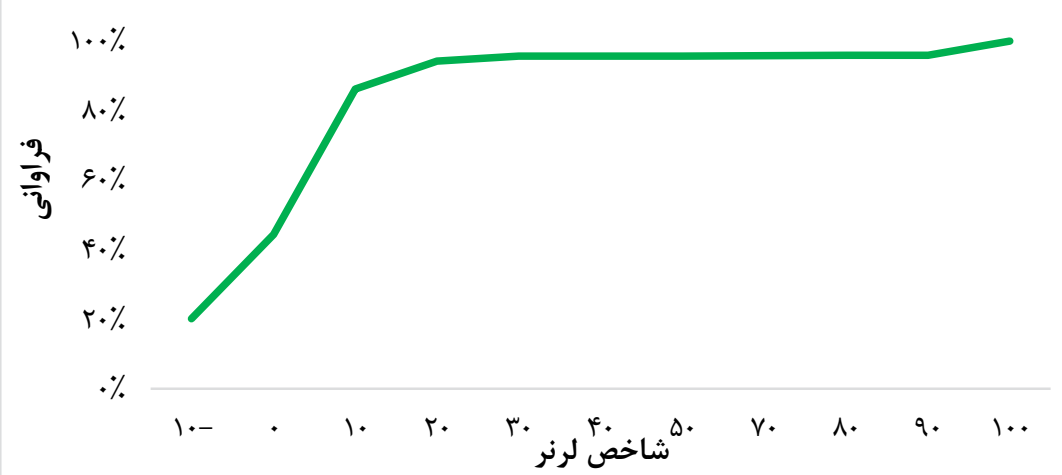

نمودار \: توزيع تجمعى شاخص لونز (براى واحدهاى با مالكيت غيردولتى)

همانطور كه مشاهده مى

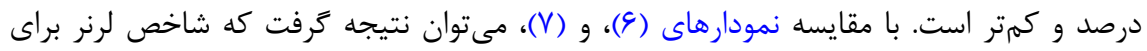

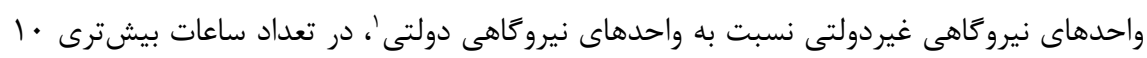

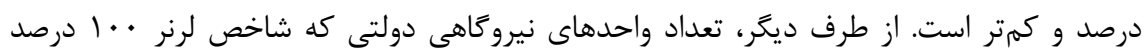

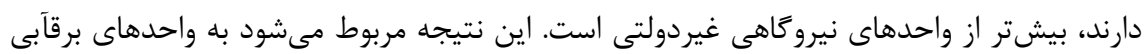
كه مالكيت دولتى دارند.

\section{بحث و نتيجه}

در اين يزوهش، عملكرد بازار عمدهفروشى برق ايران از نظر انحراف از معيار رقابت كامل در

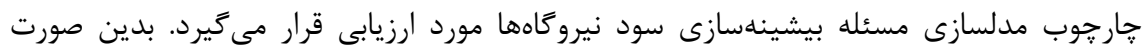

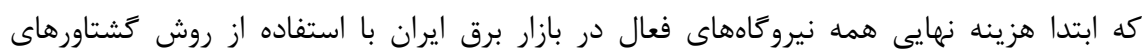
ا. تعداد واحدهاى نيرو Fاهى بع\& است كه \&ه درصد آن داراى مالكيت دولتى و ؤ درصد آن داراى مالكيت 
تعميميافته با لحاظ شرط مرتبه اول مسئله بيشينهسازى سود بنگاهها به عنوان محدوديت گشتاورى

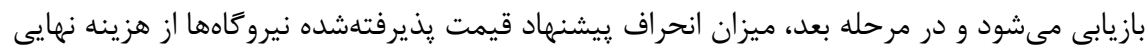

$$
\text { بازيابىشده (شاخص لرنر) محاسبه ميىشود. }
$$

نتايج برآوردهاى مدل اقتصادسنجى نشان مى دهد كه در دوره مورد بررسى (ساعات شهريور ماه

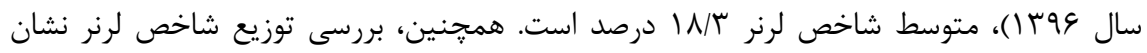

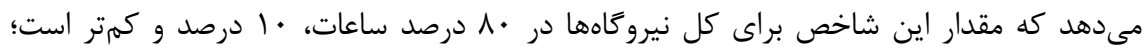

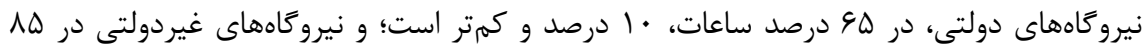

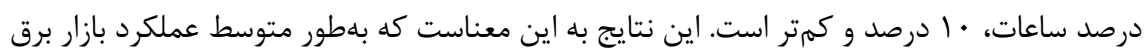

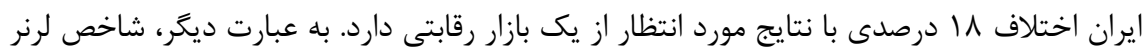

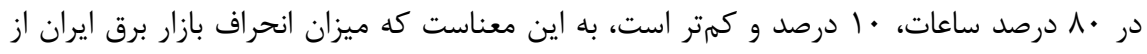

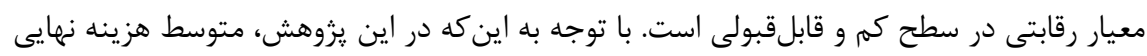

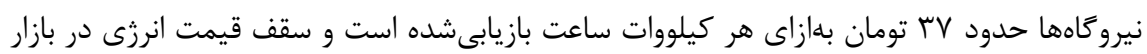

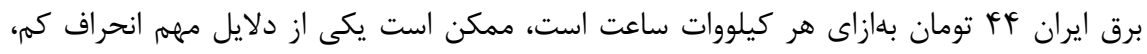

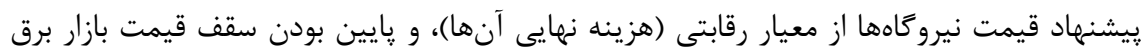

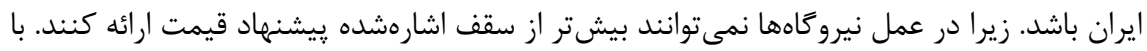

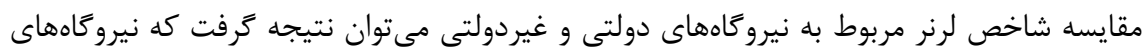

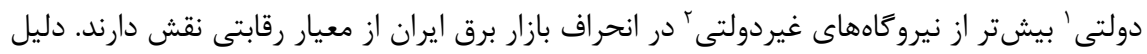

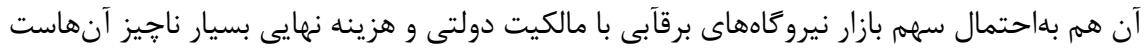

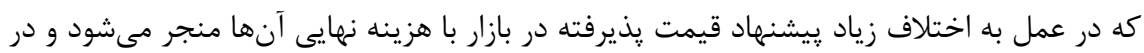

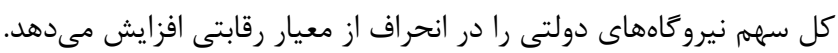

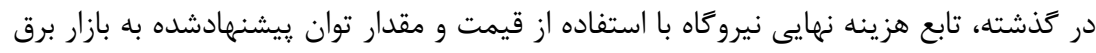

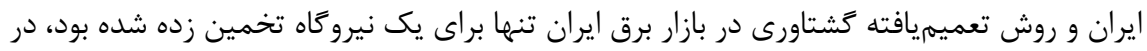

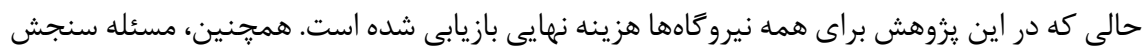

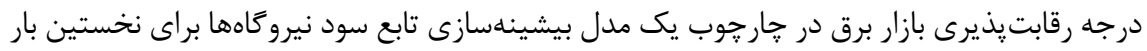

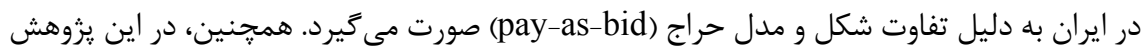

1. شاخص لرنر براى نيرو گاههاى دولتى در هـ درصد ساعات بيشتر از • ا درصد است.

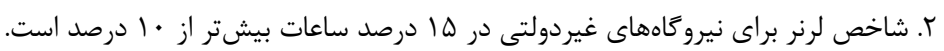


اثر مالكيت نيروگاهها بر ميزان انحراف بازار برق ايران از معيار رقابتى نيز بررسى شده است.

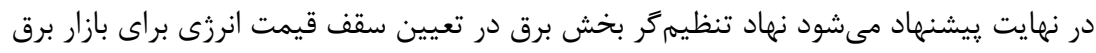
ايران بازنخرى كند و آن را افزايش دهد.

$$
\begin{aligned}
& \text { منابع } \\
& \text { الف) فارسى }
\end{aligned}
$$

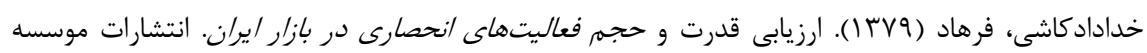

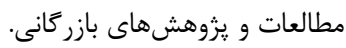

.http://jemr.khu.ac.ir/article-1-1250-fa.html

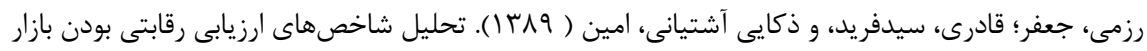

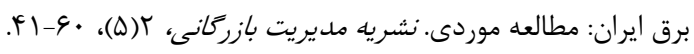

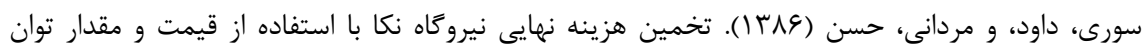

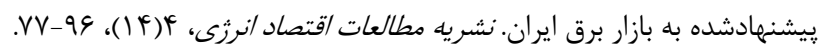

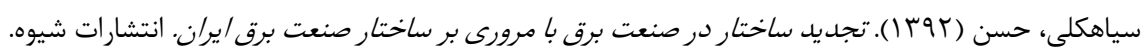

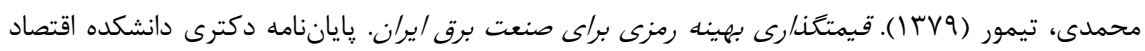
دانشعاه علامه طباطبايى.

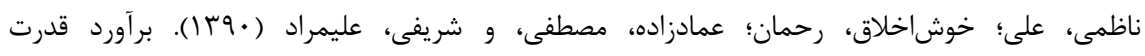

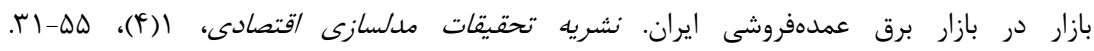

.http://jemr.khu.ac.ir/article-1-261-fa.html

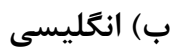

Batstone, S. R. (2000). An Equilibrium Model of an Imperfect Electricity Market. Department of Management, University of Canterbury, New Zealand.

Fatemi Ardestani, S. F., Mardani, H., \& Ghazizadeh, M. S. (2017). Testing Optimality of Firms' Actual Bid in Iran Wholesale Electricity Market. International Transactions on Electrical Energy Systems, 27(11), e2411. https://doi.org/10.1002/etep.2411.

Joskow, P., \& Kahn, E. (2001). Identifying the Exercise of Market Power: Refining the Estimates. Identifying the Exercise of Market Power. Mimeo. 
Lai, L. L. (2001). Power System Restructuring and Deregulation: Trading, Performance and Information Technology: John Wiley \& Sons.

Milgrom, P. R., \& Weber, R. J. (1982). A Theory of Auctions and Competitive Bidding. Econometrica: Journal of the Econometric Society, 50(5), 1089-1122. https://econpapers. repec.org/article/ecmemetrp/v_3a50_3ay_3a1982_3ai_3a5_3ap_3a10891122-.htm

Pineau, P.-O. (2002). Competition, Marginal Cost Pricing and Profitability in the Electricity Sector. Paper Presented at the Energy Markets in Turmoil: Making Sense of it All.

Reynolds, S. S. (2018). Measuring Market Power in Wholesale Electricity Markets: A Dynamic Competition Approach.

Rosse, J. N. (1970). Estimating Cost Function Parameters Without Using Cost Data: Illustrated Methodology. Econometrica: Journal of the Econometric Society, 38(2), 256275. https://doi.org/10.2307/1913008.

Varian, H. R. (1992). Microeconomic Analysis: WW Norton.

Wolak, F. A. (2001). Identification and Estimation of Cost Functions Using Observed Bid Data: An Application to Electricity Markets (08982937-). NBER Working Paper Series, NO. 8191.

Wolak, F. A. (2015). Measuring the Competitiveness Benefits of a Transmission Investment Policy: The Case of the Alberta Electricity Market. Energy Policy, 85(1), 426-444. https://doi.org/10.1016/j.enpol.2015.05.024. 